\title{
Tradition and Modernity in Contemporary Islamic Philosophy
}

\author{
Safet Bektovic
}

\begin{abstract}
In the aftermath of the cultural renaissance movement (nahda), especially during the second half of the $20^{\text {th }}$ century, philosophy succeeded in regaining the status it enjoyed in medieval times as an important part of the Muslim intellectual discourse. In recent decades, philosophical thought (falsafa) has gained more prominence and relevance, especially with regard to the Islamic debate about the role and function of the Islamic tradition in the contemporary modern world. In this debate, Muslim philosophers deal with various questions and issues, foremost among them: the concept of knowledge, the wider question of reform (ișläh), and the relationship between religion and secularism. How Muslim thinkers and philosophers understand the questions and how they answer them vary widely, depending on their methodological approach to these issues metaphysics, historicity, hermeneutics, and deconstruction - as well as their different positions regarding the role of philosophy in relation to contemporary Isläm in general and its role in understanding the Islamic tradition's relation with modernity in particular. The aim of this paper is to shed some light on the methodological diversity in contemporary Muslim philosophy, through readings of the work of four thinkers.
\end{abstract}

\section{Philosophical perspectives on tradition and modern challenges}

The Islamic religious tradition has always been an important subject of reflection of Muslim philosophers. The task of rethinking the intellectual traditions of Islām from a modern point of view, and the task of questioning the epistemological leanings of these traditions, became topical in the first half of the $20^{\text {th }}$ century, especially in the decades following World War II. It was a period in which many Muslim countries gained independence from both colonial powers, where the Muslim intellectual elite - lay intellectuals like the religious-minded sought ways to understand the new role of Islām in society. In a situation where different ideological movements and political initiatives were raised and promoted - e.g. Islamization of society with inspiration from classic Islamic models, the return to Islamic tradition by weighting the Islamic morals and traditional cultural patterns, the establishment of secular states according to Western models - explaining the new reality of the Muslim world became the urgent task of philosophy.

Philosophical thinking seems to be particularly relevant in discussions about Islamic reform and tradition in the light of the challenges posed by the modern Western world. This paper will shed light on four distinct philosophical positions regarding the relationship between the Islamic tradition and modernity. Each position will be exemplified by presenting a distinguished philosopher, followed by a comparative discussion of each philosopher's perspective on the issue at hand. 
Islamic epistemology and the continuity of the religious tradition: Seyyed Ḥossein Naṣr

A number of Muslim intellectuals from the second half of the 20th century were concerned with a critical analysis of Modern Western science and technology. Some of them were particularly critical of the modern Western epistemology and sought to formulate an Islamic alternative to the conception of Modern science. One of those who assumed a skeptical stance towards the modern Western concept of science was the Malaysian philosopher Naquib al-Attas (b. 1931). As a counterbalance to the secularization of knowledge, he introduced the term "Islamization of knowledge" in the 1970's as a way of "reconstructing" a concept of knowledge that is subjected to an Islamic epistemology, and hence freed from the control of secular rationalism, and, which insists on the unity between rational and revealed knowledge (Attas 2005:29-31).

Many other Muslim intellectuals adopted this idea and indulged in the task of explaining the concept of the Islamization of knowledge with the aim of designing a specific Islamic view of modern science. According to the Palestinian-American philosopher Ismā' îl Farūqū (d.1986), the Islamization of knowledge was a way to adjust modern sciences to the religious and ethical ideals of Islām, thus making them useful and relevant for Muslims in a contemporary context. Iraqi-born Ṭāha Ğābir al- 'Alwānī (b. 1935) was concerned with the anthropological aspect of knowledge and sought to formulate a synthetic igtibädmethodology by combining the doctrine of tawhid (believe in the oneness of God's nature) with a rational epistemology.

The Iranian scholar Seyyed Hossein Nașr (b. 1933) also advocates the adoption of this approach, but he rejects the possibility of reconciling secular and traditional methodology, modern and traditional science. In his view, these attempts at reconciliation are based on an epistemological break with traditional thinking and reduce reality to its material, empirical manifestations. Instead of this modern epistemology, which asserts human reason as the universal foundation of science, Nașr prefers a traditional epistemology, which maintains the unity between spirituality and reason, reason and revelation, and which, according to him, corresponds with the Islamic concept of God and its world-view" ${ }^{1}$

According to Nașr, the world must be studied as a "cosmic text", that is, as the revelation of God. However, in order to re-establish a holistic understanding of the world it is necessary to return to a traditional way

\footnotetext{
${ }^{1}$ Nașr does not make use of the term "sacred science", but insists on the Latin expression scientia sacra to emphasize that it is the metaphysical object of science, which is sacred, and not science itself. On the other hand, the object of sacred science is the manifested, phenomenological dimension of reality, and its purpose is to demonstrate that the world has a metaphysical origin (Nașr 1981a: 130-132).
} 
of thought, which insists on the unity between scientia, conceived as a rational-scientific interpretation of the world's structure, and sapientia, conceived as a Gnostic interpretation of the symbols in that structure (Stenberg 1996, Nașr 1993, 1981a).

\section{Tradition, modernity and secularism}

Nașr assumes a fundamentally skeptical stance towards Western Modernity and modern sciences. According to him, the background of Western modernity is provided by the secular humanism, whose evolution starting from the period of Renaissance has resulted in the separation of morality and knowledge from their divine origin. This is reflected in man's exploitative approach and attitude towards nature and his inability to obtain a holistic understanding of reality. It is, thus, necessary to re-establish the original relationship between man and nature and to contest the "biased" (secular) conception of reality. To accomplish this goal, traditional sciences and learning materials must form an integral part of the new educational system ${ }^{2}$. This further presupposes developing a new and powerful intellectual elite. And this was exactly what happened in some parts of the Muslim world. Muslim intellectuals and organizations, inspired by the idea of traditionalism, established during the 1980's a number of forums and centers at which they propagated traditional thinking through publications, seminars and conferences $^{3}$.

According to Nașr, the task of reviving tradition is not exclusively an Islamic one. It also concerns other religions and cultures, particularly Christianity which, according to him, faces similar challenges coming especially from secular materialism. In order to create a common cross-religious consciousness regarding traditional thought and its relevance in modern times, it is necessary to implement comparative

\footnotetext{
${ }^{2}$ Nașr is a Muslim exponent of so-called 'traditional' thought, also known as "traditionalism", is a philosophical-spiritual movement which emerged in the West in the mid-20 $0^{\text {th }}$ century and which defended the traditional religion, philosophy and science against modern secularism. Its conceptual origin could be traced back to a religious-philosophical school, which had been established during the Renaissance, known as Perennialism. The main idea of this school was that all world religions are an expression of an original, perennial wisdom, which had disappeared and which has to be revived (See e.g. Peter B. Clarke, 256$57)$.

${ }^{3}$ It is possible to identify three distinct levels within the traditionalist programme: The intellectual level, at which the main focus is to revive traditional religion, philosophy and science; the cultural level, which focuses on reviving traditional art, literature and architecture; and the social level, at which traditionalists seek to revive traditional models of social, economic and political life.
} 
studies of religion as a way of promoting and furthering an understanding of the common metaphysical origins of religion.

With respect to current tensions between Islam and Christianity, Nașr is convinced that the tension has roots neither in religion nor in ethical and moral differences, but rather in ideological factors. Apart from the secular interpretation of Christianity, he also points to the role of Muslim modernists and fundamentalists in the idelogization of Islām as another cause of this tension.

Nașr assumes a critical stance especially towards the first Muslim modernists - such as al-Afḡānī (d. 1897) ${ }^{4}$, the Indian Muslim social reformer S. Aḥmad Hān (d. 1898) ${ }^{5}$ and the Indian Muslim poet and philosopher Muhammad Iqbāl (d. 1938) ${ }^{6}$ - who advocated the reconciliation and integration of Islamic theology with modern rationalism, but who, says Nașr, had no understanding of the inner essence of Western modernity. They believed that, by accepting and adopting Western rationalism and its socio-cultural trends and models, they could minimize and overcome Western dominance over Muslims, but, instead, their work resulted in Muslims turning their backs on their own tradition and looking for answers in Western ideologies, such as nationalism, Marxism and rationalism, which all originate from a secular mindset (Naṣr 1981b: 101-102).

On the other hand, from Nașr's viewpoint, Muslim fundamentalists - let alone Wahhābīs and Salafîs - commit a great methodological error because they seek to revive the Islamic tradition without really understanding the historical background and context in which it emerged and evolved. They are concerned with the exterior forms and practices of the Islamic tradition, seeking to re-establish a system based on $S_{a r}^{-c} a$ without taking into consideration the inner dimension of the Sari ${ }^{-1} a$. The tension between Islamic modernism and fundamentalism should therefore, be seen as an expression of the Muslim misconception of both Western modernity and the Islamic tradition, says Nașr. Whereas modernists accepted the rationality of modern science as being universal without questioning its epistemological and methodological background, fundamentalists pose as radical critics of Western ideologies while, at the same time, accepting Western technology as being reconcilable with the Qur'ān and 'genuine' Islām (Nașr 1987: 18-21).

${ }^{4}$ E. Kedourie, (1997), 1-66; N. R. Keddie, (1983), esp. 36- 129.

5 See, for instance, C, Troll (ed. Mircea Eliada, 1987) "Sayyid Ahmad Khan"; also R. Hassan (ed. M. E. Sharpe, 2008), esp. 162-165.

6 See, for instance, K. G. Saiyidain, "Progressive Trends in Iqbal's Thought” (ed. M. R. Șiddīquī, 1944), 42-107; also A. Ğalāl, Self and sovereignty: individual and community in South Asian Islam since 1980 (Cambridge UP, 2000), esp. 168-72, 174-85, and 327-29; also cf. Hassan (2008), 166-70. 
As a third party Nașr identifies Muslim secularists. In his view, Muslim secularists - in their various guises - are guilty of a major error: they seek in a very artificial manner to accommodate basic Islamic beliefs with a secular worldview without understanding the relationship between the Islamic tradition and secularism and the difference between the absolute and the relative (Nașr 1987: 81-92).

According to Nasr, the Islamic tradition is neither synonymous with the Qur' ān and Sunna, nor with so-called 'genuine' Islām (which is claimed by e.g. fundamentalists). Rather, it includes the entire history of Islām, as well as all the Islamic schools and movements, Islamic art and philosophy as well as Islamic institutions and sciences, which have maintained and upheld the metaphysical foundation of Islām. Hence, although the Islamic tradition is theologically and culturally plural and diverse, it maintains and reflects one and the same metaphysics. However, ever since modern and secular ideas spread to the Islamic world in the course of the $19^{\text {th }}$ century, the survival and continuation of the Islamic tradition has been threatened, both in terms of its epistemology and the socio-religious practice of Muslims. From this perspective, therefore, an Islamic philosophy, or rather a Șüfi-based philosophy, has a main role in relation both to contemporary Islām and in the understanding of the Islamic tradition (Nașr 1981b:1-15).

\section{Criticism of the Arab-Islamic epistemology and tradition: Muḥammad A. al-Ğābirī}

In many regards the Moroccan philosopher Ğābirī (1936-2010) presents a contrary view to Nașr, especially in terms of his interpretation of the Arab-Islamic tradition and its multifold epistemologies. On the one hand, Nașr maintains continuity of tradition (from the classical period to present time), while on the other hand, Ğābirī argues for discontinuity (with the traditional thinking). At the same time, Nasr argues for a metaphysical-mystical foundation of epistemology, while Ğābirī underlines its rational foundation.

Ğābirî’s philosophical project is based on an epistemological analysis of Arab-Islamic thought. More precisely, he differentiates between two traditions of thought in Arab-Islamic culture: a mystical, gnostic system of thought, originating in the Maśriq (the eastern part of the Arab world), and a rationalist system of thought, originating in the Magrib (the western part of the Arab world). Although these two systems, and the traditions that derived from them, have not existed independently of each other and cannot be regarded as unrelated, Ğābirī aims at clarifying and emphasizing the differences between them in order to account for the relationship between the religious, mystical, and the rational aspects of the Arab-Islamic heritage, taking as his point of departure the emergence and development of classical Arab-Islamic thought. Seeking to identify and locate the rationality potentials of this thought Ğābirī ascribes a central status to the Andalusian philosopher 
Ibn Rušhd (Averröes), regarding his philosophical oeuvre as a pivotal point in the entire history of Islām, as well as an ideal of Arab-Islamic rationality.

\section{The foundation of Arab epistemology}

The foundation of Arab-Islamic reason was, according to Ğābirī, related to the determination of classical Islamic sciences, all of which can be traced back to the establishment of the first methods and models of thought that helped to shape Islām as a religious system. Within that framework, however, Ğābirī differentiates between three modes of thought in this formative period: bayān (explication, explanation), 'irfän (gnostic knowledge), and burhān (argumentation). Historically bayan is the oldest model of thought, which was established in connection with the conceptualization of Islamic philology. A key principle within this system is conclusion by analogy (qiyass), a method through which one seeks to explain the unknown by referring to the known. Originally qiyas was regarded as a methodological principle, which was especially relevant in terms of the codification of Arabic language, but was later defined as a universal method and became the leading principle in shaping specific disciplines, such as jurisprudence ( $f i q h)$ and theology ('ilm al-kaläm). Accordingly, the idea was to legislate new rules and develop legal doctrines in light of the Qur'ān and the practice of the Prophet which referred to similar circumstances and cases, and, furthermore, to explain theological problems, e.g. the justice of God and His attributes (sifat $t$ ), in analogy with the justice and attributes of man (Al-Jabri 2010: 67-68). According to Ğābirī, determining the method of analogy as a standard model of explanation already in the constitutive period of Islām (tadwinn) had begun to function as an un-reflected "mechanical operation" and a "self-referential practice" which demanded neither methodological nor analytical examination. It played a great part in developing a conventional way of thought (taqlide) through which knowledge was reproduced with a fixed reference (sacred text) without taking into account the historical development of thought and the validity of the existing rules of analogy ${ }^{7}$.

The second mode of thought, 'irfän emerged and developed under the influence of mysticism, illuminative philosophy and ancient gnostic traditions. One of the main ideas framing this system of thought is the desire to achieve a divine, prophetic experience and to reach a

\footnotetext{
7 Ğābirī acknowledges the methodological and scientific relevance of qiyās within some disciplines, but he also calls attention to its limitations and consequences. He points out that the method of analogy is only valid if it is applied to phenomena that are of the same nature in the sense of having a common element, which the analogy refers to. Hence, one can employ qiyass within linguistics and, to some extent, jurisprudence, but not within theology where the transcendent is compared to the physical (Al-Jabri 1999: 18-21).
} 
gnostic perception of the world. For Ğābirī this mindset reflects an alien element within Islām, contributing not only to a development in which the orthodoxy of Islām declined into mere artificial spirituality but also to the establishment of an interpretation which stressed the esoteric approach at the expense of the more rational and empirical approaches.

In contrast to the principles of bayan and 'irfän, the third mode of thought, burban, emerged as a result of a rational interpretation of Islām based on empirical observations and on rational argumentation, with the aim of explaining the world on its own premises and not on the premises of religion. Burbàn as a mode of thought has as its point of departure in Aristotelian rationalism was introduced to Islām by the first Muslim philosophers, al-Kindī (d. 873) and al-Farābī (d. 950), but was later elaborated and developed further by Ibn Rušd as a peculiar rationality. Unlike his predecessors (al-Farābī in particular) who had a tendency to confuse Aristotle and Plotinus, Ibn Rušd succeeded in reintroducing the "Aristotelian" Aristotle and in developing a coherent rational system of thought with a clear methodological distinction between religious and philosophical methods (Al-Jabri 1999: 43-44).

In particular, Ğābirī is very critical of Ibn Sīnā's and al-Gazālī’s way of employing burbān. These thinkers, says Ğābirī, applied burbān as a strategy to justify their mystical interpretations. They advocated a sort of pseudo-intellectual mysticism, thus betraying the principles of burban, at least as these were understood in the Aristotelian tradition. Arguably, Ibn Sinna sought to integrate Neoplatonism with Islamic theology at the expense of Aristotle, whereas al-Gazālī sought to integrate $\breve{S}^{2} \operatorname{rr}^{-1} a$ with Șuffism at the expense of a rational interpretation of $S^{5} \operatorname{arc}^{-1} a$ (Al-Jabri 1999: 57-59).

In Ğābirīs view, methodologically speaking, all mystical interpretations failed because they tended to neglect the difference between the interpreter and the object of interpretation, thus counteracting the development of a more objective, scientific understanding of reality where a critical distance to the object of interpretation is maintained.

In contrast to this method, proponents of the rationalist approach, such as Ibn Hazm (d. 1064), al-Šățibī (d. 1388) and Ibn Haldūn (d. 1406), were consistent in their employment of burbān, both as a method and as a foundation for interpretation. Ibn Hazm, for example, favored a literal and legalistic interpretation rather than mystical interpretations, while Šāțibī helped to formulate a new iğtihād in

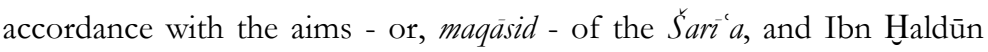
sought to explain society and history scientifically and was capable of ignoring the religious dimension.

\section{A new rational approach to modernity}

According to Ğābirī, the work of Ibn Rušd designates an "epistemological break" (qațīa ibistimüluğiyya) with mystical 
interpretations and the qiyass methodology, thus laying the ground for a new rationality based on a new interpretation of reality. Instead of compromising between revelation and reason, he accounted for their compatibility by asserting their epistemological heterogeneity. Religious problems, which relate to transcendence and metaphysics, were not to be justified by reason ( $a q)$. Conversely, philosophy, which rests on rational argumentation, was not to be judged from a religious point of view. It was in respect to these principles that Ğābirī sought to revive the way of thought which Ibn Rušd represented and to make it a normative foundation on which modern Arab-Islamic rationalism was to be based (al-Jabri 1999:128; also El-Jaichi 2010: 89-95). Just as Ibn Rušd (Averröes) marked a break with medieval interpretations, "neoAverroism" is meant to promote a similar break with contemporary Muslim intellectual discourses. This involves, according to Ğābirī, a break with dominant Arab-Muslim conceptions of tradition and modernity, especially fundamentalist and liberal readings. Both rely, to a great extent, on the classical qiyās method, thus preventing Arab-Muslim consciousness from developing in the direction of modern rationality.

Fundamentalists remain in an idealized past, as they seek to relive a fictional tradition, whereas liberals live in an un-real present, as they seek to implement Western models in an idealized context. Neither group succeeds in creating a realistic vision for Arabs/Muslims based on an objective interpretation of the tradition and of existing socio-political conditions. On the contrary, the former group presents and maintains a false idea of Islamic "authenticity" (așāla), whereas the latter suggests an alienated image of Islamic modernity (Al-Jabri 1999: 10).

Ğābirī also refers to a third approach - Arab Marxism - that, according to him, failed in the same way at similar critical points. Arab Marxists, he says, were also concerned with implementing a ready-made method, in this case historical materialism, without taking into account the peculiarities of Arab history and the real challenges existing in contemporary Arab societies (Al-Jabri 1999: 13-14). In connection with his criticism of the Arab reason (al-'aql al-'arabi), Ğābirī questions also the status of language and its role in the development of Arab-Islamic rationality. The traditional Arab way of understanding language as something that is normatively based on the Qur'ān, has, according to Ğābirī, limited the possibilities of interpretation. Because language has been regarded as a "sacred tool" for interpretation, it exerted a "sacred influence" on the reader, which in turn has prevented the Arab and Muslim reader from pursuing an independent and objective relation to the text (El-Jaichi 2010: 39-45). Instead, the Arab Muslim reader appears as someone who submits himself to the structure of the text. One can argue that this is due to an ontologization of the Arabic language, which occurred in relation to the first interpretations of the Qur'a an and which was encouraged and supported by Muslim rulers who wished to maintain the religious vocabulary as a legitimizing tool. Classical scholars further contributed to this development as they allied themselves with the rulers and used the religious system of language as a way to limit and 
exclude alternative interpretations. In order to establish a modern ArabIslamic science of language it is necessary in Ğābirīs view to carry out a critical analysis of the meaning of language, including an analysis of the relationship between religious and non-religious (i.e., secular) languages, with the goal of liberating language and interpretation from religion. One must simultaneously carry out a critical analysis of the ideological foundation of Arab-Islamic philosophy that takes seriously the role of philosophy in relation to dominant structures of power (Al-Jabri 1999: 26-27).

\section{Transformation of tradition to modernity: Ḥassan Ḥanafī}

Perhaps no other philosopher has marked Egypt's intellectual and political life the way in which the Egyptian-born Hassan Hanafi (b. 1935) has. Since the 1960s Hanafi has been personally involved in the political life of the Egyptian society. Hanafi has gone through different phases of development, dedicated to very ideological positions at different times ${ }^{8}$, a fact, which makes it difficult to fix his position within the Muslim philosophical landscape. John Esposito has referred to Hanafì as holding a middle position between, on the one hand, the conservative and fundamentalist wing and, on the other hand, the secularist and communist wing. This middle stance is most clearly seen in Hanafi's endeavor to establish an Islamic left-wing, which builds on a continuation of M. 'Abdu's reformist ideas with the ideological goal of reconciling Egyptian political movements and religious trends (Esposito 2001: 70).

Basically speaking, Hanafi's project aims to renew Arab-Islamic consciousness on the basis of a hermeneutic interpretation of the Qur'ān. He sees the Qur'ān as a multifocal phenomenon: a juridical code, a literary work, a philosophical text and a historical document. Inspired by Dilthey, Gadamer and Ricoeur he maintains that any interpretation is conditioned historically and determined by the interests and motivations of the interpreter. According to Hanafi, this is a reflection of the different traditions of interpretation and the intraMuslim discussions on the interpretation of the Qur' ān, which have largely been characterized by specific political interests and confessional motivations (Hanafi 1995, I: 416-417). The text in itself is empty and, as such, the words are given meaning by the interpreter. Seen

8 To begin with the Islamism of Sayyid Qutb attracted him, and by the age of 16 he had already joined the Muslim Brotherhood. However, when he began his philosophical studies he became more concerned with the modernist ideas of 'Abduh. He later argued for Islamic socialism and ultimately became a proponent of an Islamic theology of liberation and of a hermeneutical re-reading of the Islamic sources as the basis for a religious and political transformation of Muslim consciousness. 
retrospectively the Qur' ān is a text that emerged in the past, and is therefore filled with content and meaning that reflects the sociohistorical context in which it was written. The method, which helps us to both create meanings and understand the continuity between past, present and future, is hermeneutics (Hanafi 1995, II: 186).

When dealing with hermeneutics of the Qur'ān the point is to understand, first and foremost, the connection between the Qur' ānic passages which are "born into history", and their "meta-historical background." This can be achieved through a double movement: from text to reality and then from reality to text. The first movement is facilitated by employing the anthropology of language, which makes it possible to differentiate between the literary and the figurative, the exoteric (al-zähbir) and the esoteric (al-bätin), whereas the second movement requires one to understand the spirit of the time in which the interpreter lives, which in turn makes possible the appreciation of a Qur'ānic normativity (Hanafi 1995, II: 187).

The renewal of Islamic thought also involves a revaluation of classical Islamic sciences (kaläm, falsafa, Șüfism and fiqh) with the goal of critically inquiring their role in shaping the contemporary Islamic consciousness. According to Hanafi, these sciences have, each in their own way, contributed to the communication and transmission of God's revelation: theology (kaläm) has done so by formulating doctrines; philosophy (falsafa) by formulating worldviews and conceptions of man; Șūfism (tașawwuf) by describing spiritual experience; and jurisprudence (fiqh) by expounding Islamic law. However, he argues that the main purpose of interpreting Islām must be to provide answers to existing challenges.

One of the main challenges facing Islamic sciences today is to explain the relation between facts and values. In order to do so they must apply and integrate modern methods such as hermeneutics and phenomenology. Whereas hermeneutics helps us understand the relationship between the normativity of the Qur'ān as a primary frame of reference, phenomenology can help us understand the relationship between facts and values, between "being" and "having to". According to Hanafi, every fact reflects a value, whereas every value refers to a nonrealizable fact. Some of the examples of the relation between a value and a fact within Islām are as follows: God's Speech is a value, prophecy is a fact; the unity of God is a value, justice is a fact; hope is a value, eschatology is a fact (Hanafi 2006: 232-234).

\section{Universality and particularity of tradition and modernity}

On the basis of this renewal theory vis-à-vis the Islamic cultural heritage (al-turät wa-l-tağdìd) Hanafī argues for a specific Islamic understanding of modernity based on a harmonious relationship between tradition and modernity. In this connection, he rejects the West's claim to be 
representing a universal modernity, pointing out that Western values, like Islamic values, are also bound by time and space, and thus cannot be regarded as universal.

According to Hanafi, every tradition is characterized by a specific potential for development and by some specific possibilities for modernization. Accordingly, modern Western progress emerged as a result of a dialectic relationship between different elements which all played a part in influencing and shaping Western tradition. Hence, the Islamic path to modernity presupposes and requires a renewal of specific Islamic cultural values (material as well as spiritual) that have characterized Islamic tradition.

More specifically, Hanafî is interested in the plurality of models for progress and has thus accounted for different forms of progress: the scientific, the material, the intellectual and the moral. He further points out that different civilizations and societies have undergone different forms of progress. For instance, ancient Egypt experienced a remarkable mathematical and astronomical progress, ancient India experienced a characteristic spiritual progress, Persia experienced an institutional progress, Hellenistic Greece a philosophical progress, the Roman Empire a juridical progress etc. It is therefore wrong to conclude, based on current conditions and the fact that some areas and cultures have become modern while others continue to be determined by a premodern worldview, that progress is only possible within a specific geographical and cultural-historical frame or that it has a universal form.

Modernity, Hanafĩ argues, does not necessarily denote a break with tradition. Rather, the relationship between tradition and modernity reflects a tension between continuity and discontinuity. However, the two categories are not to be understood as fixed entities as they are primarily methodological tools, which have the function of explaining the relationship between past and present and of constructing a corresponding identity. Drawing on the (Heideggerian) term Dasein as an expression of the timely continuity of existence, Hanafi argues that the emphasis of continuity and discontinuity is always determined by our approach to the problem of identity. Continuity is motivated by the idea of recognizable identity, whereas discontinuity is motivated by the idea of difference (Hanafi: 2005).

To an extent, therefore, all traditions consist of something universal and something particular and have a potential for renewing themselves. Furthermore, renewal is not necessarily synonymous with discontinuity as is exemplified by e.g. the Asian traditions (Japanese and Korean societies), which are traditional and modern at the same time. Still, Western countries have developed a dichotomous understanding of the relationship between tradition and modernity, which has been used as a model of interpretation in order to draw a clear boundary between the West and the so-called third-world countries.

Muslims can be modern without having to imitate the West. Indeed, Hanafi describes the Islamic way to modernity as a "change through continuity", where the goal is to maintain the link between the old (al- 
qadim) and the new (al-ğadìd). Philosophical hermeneutics plays a special role in this process. Not only does it account for the historical significance of revelation, it also promotes an understanding of the relationship between the universality of Islām and its manifold interpretations (Hanafi 2005: 391-392).

\section{Deconstruction of Islamic orthodoxy and tradition: Muḥammad Arkoun}

Unlike Nașr, Hanafī and Ğābirī who all operate with the same notion of a genuine or 'authentic' Islām, Arkoun's work settles with the idea of authenticity and his epistemology is of an entirely different type. He is fundamentally critical of any logocentic thinking whether it relates to contemporary Western or Islamic paradigm. He considers the logocentric approach to Islām as both hegemonic and reductive, and of having ultimately contributed to the mythologization and ideologization of Islām. In this sense Arkoun criticizes the Western interpretation of Islām as positivist and static viewing Muslim text sources as the central fixation point. This has the effect of reducing Islām to a dogmatic entity and Muslim communities and practices as empirical versions hereof. Arkoun is also critical of Muslim interpretations of Islām (traditional as well as modern), arguing that they are based on essentialist and ideological approaches to Islām, as they also share a common reference in an idealized past in a way that seeks to reconstruct a "genuine" or authentic Islām based on the idea that an ultimate interpretation of Islām is possible.

In contrast to these approaches, Arkoun seeks to implement - at least according to his own claims - a new inter-disciplinary approach, within the framework of what he calls "applied Islamology", with two aims: (1) "a critical re-reading of the exhaustive Muslim Tradition, free from the dogmatic definitions of the existing literature on schools; and (2) the historicizing of contemporary Muslim discourse, which has been characterized by ideological references" (Arkoun 1997: 41). In addition, Arkoun uses the term "historical epistemology" to emphasize that the core of "applied Islamology" is not the interpretation itself, but the understanding of the historicity and plurality of interpretations within Islamic culture (Arkoun, 2006: 17-23, 97).

His starting point is a structural analysis of the ideologicalepistemological background of the various forms under which Islām appears in our days. More precisely, Arkoun is interested in the orthodox interpretation, the deconstruction of which he considers as very crucial in this analysis. In a broad sense, the primary aim is to understand how orthodox Islām has evolved. Who defined orthodoxy and heresy, and what were the social, political and ideological factors that contributed to the making of orthodoxy in Islām? How and under what circumstances were certain interpretations appropriated as 
legitimate and correct, while others were rejected as illegitimate and heretical?

Indeed, Arkoun turns the normativity and cognitive aspects of the Qur'ān upside down arguing that the revelation (al-wahy) was not to be understood as a normative speech, within which God orders Muslims to perform specific rituals and actions, but rather as a set of analytical categories and "meanings" to be understood within the framework of an "alliance" between man and God. The Qur'ānic verse 12:2, "We have sent it down as an Arabic Qur'ān so that you [people] may understand" implies, says Arkoun, that the Qur'ān was introducing a new "hermeneutic situation in Arabic", within which the interaction between the new idiom, the Qur'ānic language and the existing Arabic mentality resulted in the creation of a new normativity (Arkoun, 2009: 49-52).

The collection and canonization of the revelations was the most central event in the history of the Qur'ān because it turned the Qur'ān into an "officially closed corpus". It also invalidated the original openness that characterized the Qur'ānic revelations. In order to come to an understanding of this openness and the possible interpretations of the Qur'ān, it is necessary, according to Arkoun, to deconstruct the theological and political mechanisms, which played a part in determining the official interpretation. This implies the application of an archaeological method that is capable of uncovering the interplay between social, political and ideological factors, which formed part of the original context in which the collection and canonization of the Qur'ān took place (Arkoun 2006: 86-88).

A first step towards realizing this goal is the understanding of the so-called le fait islamique ${ }^{9}$, which includes the dogmatic, religious, ethical, cultural, ideological and social aspects of Islām and refers to the period when Islām was consolidated, i.e. from Prophet Muhammad's death in year 632 to approx. 950, when the more influential orthodox schools determined the framework within which Islām was to be interpreted.

It was during this period that Islamic orthodoxy was formulated and defined. In Arkoun's view, since then Islamic thought has been characterized by a dogmatic interpretation of the Qur'ān, which in turn

\footnotetext{
${ }^{9}$ In order to describe the Islamic discourse from the period of revelation and its historical development, as well as the interpretation of the Qur'ān during the time of Prophet Muhammad and after his death, Arkoun introduced two key-terms: le fait coranique and le fait islamique. Le fait coranique can be translated as the Qur'änic fact or event, which denotes both a linguistic phenomenon and a mystical experience, i.e. the Prophet's oral transmission and dissemination of the Revelation with reference to the existing mythological worldview as an interpretational horizon. Le fait islamique designates the consolidation of the "Qur'anic event”, and emphasizes the fact that the Qur'ānic revelations, as these were collected and canonized in a book (Mushaf) by the earliest authorities, became the basis of Islamic orthodoxy, which also assumed an important role as a "Closed corpus" (Arkoun, 2006: 272-273, 280282).
} 
further reduced the Qur' ānic discourse to a holy scripture (or a divine "pre-text") while the Hadī collections and juridical regulations have been pronounced as the dogmatic key references for interpretation.

Arkoun argues for a new, open and pluralistic epistemology and depicts this as the path to the emancipation of the (post-) modern human being from reductive and triumphal positivistic reason, which he refers to as 'tele-techno-scientific reason' (Arkoun 2006: 37,). Arkoun, it is true, takes the post-modern criticism of modernity as his starting point. But he does not align himself with Western post-modernism. He calls for the inclusion of marginal and peripheral interpretations, and he upholds the relevance of the transcendent as part of the new epistemology. In this respect, he is in accord with Derrida in his deconstruction of 'the imaginary', but he also acknowledges 'the transcendent signifier' as a reference in the actual deconstruction. Arkoun's approach thus can neither be considered religious nor secular, modern nor post-modern, in the strict meaning of these terms. Rather, his approach is an all-inclusive humanism, striving towards what he calls a 'meta-modernity' that transcends both modernity and post-modernity (Arkoun 2009: 18-19, 2006: 55).

Indeed, according to Arkoun, only an open epistemology enables an understanding of the universality and diversity of Islām. Existing theories on what is universal and diverse in Islām have emerged as the result of a dialectic between two contradictory tendencies: one that has constantly sought to unify and sacralize Islām, by constantly maintaining the sacred Tradition (with a capital "T"), and another that has sought to uncover the sacred and mark the human by emphasizing the local ethnic traditions (with a small "t") (Arkoun 2006:265-266). In order to reach an understanding of Islām in its multifarious facets, including the historical link between the sacred and the human, the orthodox and the heterodox, it is necessary to re-think or better said deconstruct all the interpretative traditions (the approved as well as the non-approved) making at the same time room for new potential interpretations.

\section{Conclusion}

In the above presentation of four modern Muslim philosophers - Nașr, Hanafî, Ğābirī and Arkoun - one can distinguish between two different but interrelated discussions: one theoretical, and the other practical. The theoretical discussion is closely linked to the role of philosophical interpretation, its objective, and its position (within the Islamic discourse) in relation to other disciplines; the practical discussion relates to the question of political engagement of intellectuals and the implications of this engagement on their philosophical thought.

In terms of the first mentioned area of discussion, it seems that all four agree that philosophy has a central and decisive role in the interpretation of Islām but from different angles. Hanafì and Arkoun are occupied with the interpretation of the Qur'ān as a starting point for 
validating their respective claims about the significance of philosophy, while Nașr and Ğābirī (in different ways) consider the theological constitution of Islām as a basis for understanding the entire development of Islām. But they share a common idea: there can be no understanding of the Islamic tradition without philosophical analysis and no adequate understanding of modern challenges is possible without philosophical reflections on Islām's relationship with modernity. In this regard one must also take note of the fact that these thinkers define Islamic philosophy terms of a certain understanding of its status and function vis-à-vis the question of modernization of Arab-Islamic culture, of the return to the cultural heritage of Islām:

a) to underpin a theological-metaphysical essence of the Islamic philosophical tradition, arguing for its un-changeability and its incompatibility with modernity (Nașr); b) to explain its transformative potential, arguing for modernization as a function of the Islamic philosophical tradition and its dynamism (Hanafî); c) to reconstruct its dogmatic structure in order to define an new modern and more appropriate method of philosophical interpretation in Arab-Islamic culture (Ğābirī); d) to deconstruct the ideological background of falsafa in order to keep all interpretations open, transcending both its traditional and modern models (Arkoun). Unlike Nașr, who maintains the position of philosophy within the so-called traditional thinking and traditional science, the last three are open to modern human sciences, and advocate more or less a multidisciplinary approach as an optimal framework for the exercise of philosophy.

Hanafī and Ğābirī were both politically active and they worked from a conviction that their engagement is the best way to influence the development of society. Both were concerned with the development of their home countries and made a great effort in giving philosophical ideas a crucial role in the process of shaping modern Muslim identity. Although their own philosophical ideas were not easily accessible and directly attractive to the general population, they found ways to influence the development at the wide grass-root level. This they were able to do partly due to the fact that they had a socio-political role as university professors engaged in disseminating their ideas by taking part in public debates, as well as publishing popular and politically relevant texts. On the other hand, neither Naṣr nor Arkoun was politically engaged having the largest part of their career established outside their home countries, Nașr in USA and Arkoun in France. Before the revolution in 1979, however, Nașr was very dedicated to the establishment of philosophical studies in Irān where he had good relations to king Šhāh. After the revolution he assumed a key role, this time, however, in a project endeavored to the "Islamization of knowledge" and the establishment of Islamic educational institutions around the world. So unlike Arkoun he is known as a very engaged intellectual. Arkoun's involvement was primarily academic and his ideas have had only an indirect impact on the general Muslim public. His works might acquire more influence in the 
near future especially amongst the new generation of Muslim intellectuals, in the Arab world through translations as well as in Europe.

\section{Appendix:}

A Schedule of comparison of the understanding of Islamic tradition and the role of philosophy in the interpretation of Islām:

\begin{tabular}{|c|c|}
\hline Seyyed Ḥossein Naṣr & Ḥassan Ḥanafí \\
\hline 1. Islamic tradition as a continuity & 1. Islamic tradition in process of changing \\
\hline $\begin{array}{l}\text { 2. Philosophy seeks to explain the metaphysical truth of } \\
\text { Islām }\end{array}$ & $\begin{array}{l}\text { 2. Philosophy seeks to explain historical truth of Islām } \\
\text { (relationship between tradition and modernity) }\end{array}$ \\
\hline $\begin{array}{l}\text { 3. Philosophy helps to understand and preserve the } \\
\text { non-changeability of Islām }\end{array}$ & $\begin{array}{l}\text { 3. Philosophy helps to create a new, reformed Islamic } \\
\text { consciousness }\end{array}$ \\
\hline $\begin{array}{l}\text { 4. Philosophical thought is in its essence religious } \\
\text { (prophetic philosophy) }\end{array}$ & $\begin{array}{l}\text { 4. The philosophical and the religious thought used to } \\
\text { be in harmony }\end{array}$ \\
\hline $\begin{array}{l}\text { 5. Philosophy is based on a traditional epistemology } \\
\text { and has no need of modern humanistic science }\end{array}$ & $\begin{array}{l}\text { 5. Philosophy should integrate modern sciences, like } \\
\text { phenomenology and hermeneutics }\end{array}$ \\
\hline Mohammed Al-Ğābirī & Muḥammad Arkoun \\
\hline $\begin{array}{l}\text { 1. Islamic tradition is ambiguous (bayān, 'irfän and } \\
\text { burbān) }\end{array}$ & 1. Islamic tradition as a construction \\
\hline $\begin{array}{l}\text { 2. Philosophy seeks to explain the constitution of } \\
\text { Islamic reason }\end{array}$ & $\begin{array}{l}\text { 2. Philosophy seeks to deconstruct the 'authentic' Islam } \\
\text { (deconstruction of orthodoxy) }\end{array}$ \\
\hline $\begin{array}{l}\text { 3. Philosophy helps to make an epistemological break } \\
\text { with traditional thought/consciousness (bayān and } \\
\text { 'irfän) }\end{array}$ & $\begin{array}{l}\text { 3. Philosophy helps to demystify and de- ideologize } \\
\text { Islamic consciousness and identity } \\
\text { 4. Neither religious nor secular thought but humanistic } \\
\text { thought }\end{array}$ \\
\hline $\begin{array}{l}\text { 4. The philosophical and the religious thought must be } \\
\text { separated (new- averröism) }\end{array}$ & $\begin{array}{l}\text { 5. Philosophy should be part of an interdisciplinary } \\
\text { endeavour (e.g., "applied islamology") }\end{array}$ \\
\hline $\begin{array}{l}\text { 5. Philosophy should include modern sciences like } \\
\text { anthropology and linguistics }\end{array}$ & \\
\hline
\end{tabular}




\section{Author biography:}

Safet Bektovic is associate professor at the Faculty of Theology at the University of Oslo. His teaching and research include Islamic philosophy, European Islam, ethics and Sufism. Among his publications are Islamisk filosofi: Baggrund, problemstillinger og moderne udformninger (Islamic philosophy: Background, Classical Problems and Modern Expressions”), Copenhagen, 2012 and Kulturmøder og religion (Cultural encounters and religion), Copenhagen, 2004.

\section{References}

Al-Attas, Naquib, Muhammed, Seyed, 2005: Islamic Philosophy: An Introduction. Journal of Islamic Philosophy 1, pp. 11-43. www.muslimphilosophy.com

Al-Jabri, Abed, Mohammed, 1999: Arab-Islamic Philosophy. A Contemporary Critique, Institute for Maghrebi Studies, Austin.

Al-Jabri, Abed, Mohammad, 2010: The Formation of Arab Reason: Text, Tradition and the Construction of Modernity in the Arab World. I.B. Taurus, London.

Arkoun, Mohammed, 1997: "The Study of Islam in French Scholarship" in: Mapping Islamic Studies Ed. by Azim Nanji, Walter de Gruyter. Berlin New York, pp. 33-68.

Arkoun, Mohammed, 2006: Islam. To Reform or Subvert? Saqi Books, London.

Arkoun, Mohammed, 2009: Den arabiske tænkning. Forlaget Gramma, København.

Clarke, Bernard P, 1997: New Trends and Developments in the World of Islam. Midpoint Trade Books Incorporated

Eliade, Mircea ed., 1987: The Encyclopaedia of Religion, vol. 1, Macmillan Publishing Company, New Tork.

El-Jaichi, Saer, 2010: Et arabisk-islamisk rationalitetspotentiale? En undersogelse af Mubammad A. al-Jabiris kritik af den arabiske fornuft. Forlaget Gramma, København.

Esposito, L. John \& Voll, O. John, 2001: Makers of Contemporary Islam, Oxford University Press, Oxford. 
Hanafi, Hassan, 1995: Islam in the Modern World Vol. I and II. The AngloEgyptian Bookshop, Cairo.

Hanafi, Hassan, 2005: "Tradition and Modernism between Continuity and Discontinuity. Possible Models and historical Options". Asian Journal of Social Science. Volume 33. Number 3. pp. 384-393.

Hanafi, Hassan, 2006: "Facts and Values: An Islamic Approach" in: (ed) Mehran Kamrava: The New Voices of Islam. Reforming Politics and Modernity I. B. Tauris, London, pp. 231-241.

Keddie, N. R. 1983: An Islamic Response to Imperialism: Political and Religious Writings of Sayyid Jamāl Al-Din al-Afghāni, University of California Press, California. First Published: 1968.

Kedourie, E, 1997: Afghani and 'Abdub: An Essay on Religious Unbelief and Political Activism in Modern Islam, Psychology Press, New York. First Published: 1966.

Ğalāl, A, 2000: Self and sovereignty: individual and community in South Asian Islam since 1980, Cambridge University Press, Cambridge.

Nasr, Hossein, Seyyed, 1973: "The Meaning and Role of Philosophy in Islam”. Studia Islamica, No. 37 pp.57-80. Maisonneuve \& Larose. JSTOR.

Nasr, Hossein, Seyyed, 1987: Traditional Islam in the Modern World. Kegan Paul International, London.

Nasr, Hossein, Seyyed, 1981a: Knowledge and the Sacred. Edinburgh University Press, Edinburgh.

Nasr, Hossein, Seyyed, 1981b: Islamic life and thought. Allen and Unwin, London.

Nasr, Hossein, Seyyed, 1993: The Need for a Sacred Science. Albany. State University of New York.

Sedgwick, Mark, 2004: Against the modern world. Traditionalism and the secret intellectual history of the twentieth century. Oxford University Press, Oxford.

Stenberg, Leif, 1996: The Islamization of Science. Four Muslim Positions Developing an Islamic Modernity. vol. 6. Lund Studies in History of Religions, Lund.

Saiyidain, K. G. 1944: "Progressive Trends in Iqbal's Thought": (ed.) M. R. Șiddīquī, Iqbal as a thinker: essays by eminent scholars, Shaikh Muhammad Ashraf, Lahore, pp. 42-107. 